\title{
Graduates of a public university and perspectives of performance in nursing management*
}

\author{
Egressos de uma universidade pública e perspectivas de atuação no gerenciamento em \\ enfermagem
}

\section{Graduados de una universidad pública y perspectivas de la gestión del rendimiento en enfermería}

\begin{abstract}
Maria de Lourdes de Almeida ${ }^{1}$, Aida Maris Peres ${ }^{2}$, Elizabeth Bernardino ${ }^{2}$, Marieta Fernandes Santos ${ }^{1}$
\end{abstract}
\begin{abstract}
A study with a qualitative approach aiming to analyze the influence of undergraduate education on preparing for management in Nursing. The study was conducted with 22 graduates from a Public University in Southern Brazil. This research had data collected between the months of February and April through semi-structured interviews. Data was analyzed by the Collective Subject Discourse technique. The study was approved by the Ethics Committee of the Federal University of Paraná. The following central ideas were found as a result: how undergraduate studies influence professional performance; use of managerial tools in managerial procedures; gaps found in subjects' practical training sessions; suggestions for improvement. The research revealed fragmentation of subject contents, managerial procedures of doing with a productive approach, the need of curricular restructuring, improve training in the field and teaching/work partnership improvement. It is difficult for nurses to understand the managerial scope of its working process and to develop managerial competencies in professional practice.
\end{abstract}

Descriptors: Nursing Education; Nursing Administration Research; Professional Competence.

Objetivou-se analisar a influência da graduação no preparo para o gerenciamento em Enfermagem com 22 egressos de uma Universidade Pública do Sul do Brasil. Pesquisa de abordagem qualitativa, cuja coleta de dados ocorreu nos meses de fevereiro a abril de 2010, por meio de entrevistas semiestruturadas. Os dados foram analisados pela técnica do Discurso do Sujeito Coletivo. Como resultados surgiram as ideias centrais: influência da graduação na capacitação; utilização de instrumentos gerenciais nas ações gerenciais; lacunas na parte prática das disciplinas; sugestões para mudanças. Apontouse a fragmentação dos conteúdos das disciplinas, ações gerenciais com enfoque produtivista no fazer, necessidade de reestruturação curricular, melhoria nos campos da prática e das parcerias ensino/serviço. Há dificuldades para o enfermeiro perceber a dimensão gerencial no seu processo de trabalho e desenvolver competências gerenciais na prática profissional. Descritores: Educação em Enfermagem; Pesquisa em Administração de Enfermagem; Competência Profissional.

El objetivo fue analizar la influencia de la graduación en la capacitación para gerencia en enfermería con 22 graduados de una Universidad Pública del Sur del Brasil. Investigación cualitativa, cuya recolección de datos ocurrió entre febrero y abril de 2010 a través de entrevistas semiestructuradas. Los datos fueron analizados por la técnica del Discurso del Sujeto Colectivo. Como resultados surgieron las ideas centrales: influencia de la graduación en la capacitación; uso de instrumentos gerenciales en las acciones gerenciales; vacíos en la parte práctica de las disciplinas; sugerencias para cambios. Se señalaron la fragmentación de contenidos de las disciplinas, acciones gerenciales con enfoque productivista en el hacer, necesidad de reestructuración curricular, mejora en los campos de la práctica y de las parecerías enseñanza/servicio. Hay dificultades para el enfermero percibir la dimensión gerencial en su proceso de trabajo y desarrollar competencias gerenciales en la práctica profesional.

Descriptores: Educación en Enfermería; Investigación en Administración de Enfermería; Competencia Profesional.

"Article taken from the paper "Gerenciamento em Enfermagem: formação e prática na perspectiva de egressos de uma universidade pública”, Universidade Estadual do Oeste do Paraná, 2010.

${ }^{1}$ Universidade Estadual do Oeste do Paraná. Foz do Iguaçu, PR, Brazil.

${ }^{2}$ Universidade Federal do Paraná. Curitiba, PR, Brazil.

Corresponding author: Maria de Lourdes de Almeida

Rua Tarquínio Joslim dos Santos, 1.300, CEP: 85.870-650. Foz do Iguaçu, PR, Brazil. E-mail: m_lourdesdealmeida@yahoo.com.br 


\section{Introduction}

The Unified Healthcare System bases its conception in universality, comprehensiveness, decentralization and social participation. It was conceived as a result of the Brazilian Healthcare Reform movement that recognized healthcare rights and state responsibilities described in the Constitution of $1988^{(1)}$.

With regard to the consolidation of this system, there are major challenges to overcome. The changes in the healthcare model demand new professional profiles able to act accordingly. Facing the new scenario changes in nursing education (with particular reference to its management training) have been considered.

The partnership between the Ministry of Health and the Ministry of Education in 2001 resulted in the establishment of National Curriculum Guidelines for Undergraduate Courses and among other courses nursing. This article describes that nurse training should prepare future nurses to meet social health needs, including the acquisition of knowledge, skills and approaches required to develop and compose basic skills that support their actions in different fields of $\operatorname{action}^{(2)}$.

Faced with this in Brazil, nursing management has been considered an indispensable part of the practice of nursing, regardless of the occupied positions or functions. The managerial dimension outweighs the nurse's work, considering that this professional coordinates the work of health and nursing staff and also plans and organizes the work to ensure adequate conditions for the provision of care $^{(3)}$.

Management permeates the professional nursing practice at various levels of health care, aiming towards improving the quality of services provided to people, family and community as an organizing tool for health services. Thus, it is essential to expand knowledge in order to act more effectively in management issues $^{(4)}$.

The nursing services in health institutions have its management privately exercised by nurses, accor- ding to Law No. 7498 of 25 June 1986. This law provides for the regulation of nursing practice in Brazil. In Article 11, it is stated that the direction and organization of the nursing body, integrated with the basic structure of the health institution, public and private, and the heads of service and the nursing unit are up to the nurses; the technical activities, operations, planning, coordination, implementation and evaluation of nursing care $^{(5)}$.

However, it is necessary for the nurse to understand the relevance of managerial dimension to their work process so there is overcoming dichotomy between assistance and administration/management, and thus act with a critical view of reality in different contexts $^{(6)}$.

This issue becomes important due to the fact that management integrates nursing work and can be seen as a result of historical composition of its workforce, characterized by technical and social division with separation between design and implementation, when the various work processes of this person are considered. Thereby highlighting the subprocesses of care/assistance, administer/manage, teaching/research ${ }^{(7)}$.

In the context of nursing education to the world of work, the teaching of Nursing Administration may constitute an instrument that will make a difference in mobilizing knowledge for managerial performance of this professional in the various levels of health care. This is providing that teachers evaluate the training of students in relation to training for management being important for its social responsibility to train nurses prepared to meet the demands of health services.

The study of nursing education for the managerial dimension should be targeted to the development of this profile, to which the professional is able to act in management with the understanding that by doing so they are managing the care and thereby also providing assistance (indirect care).

The focus of this research is the study on training to prepare nurses to take over management in all areas and contexts of activity, as instructed in the 
National Curriculum Guidelines for nursing education in Brazil.

Based on these, the aim was to analyze the influence of undergraduate nursing management disciplines to prepare them for Nursing management.

\section{Methods}

This research is characterized as a descriptive and exploratory qualitative study. These studies are able to absorb theme from meaning and intentionality as a characteristic of social relationships, actions and structures in order to understand the internal sense of groups, institutions and individuals on cultural values, peoples interactions, institutions, social movements and historical processes ${ }^{(8)}$.

The sample consisted of 59 alumni who graduated in 2007, 2008 and 2009 from the Nursing Course at the State University of Western Paraná, campus of Foz do Iguaçu. Participants data (such as email and telephone) were provided by the academic department of the institution after formal request by the author.

22 graduates of both genders participated in the research which had the following as inclusion criteria: agreeing to participate; and having over six months of professional experience in any area of nursing. Exclusion criteria were: refusing to participate or having less than six months of experience. It was considered that training needs to provide nursing graduates with the concept of inseparability between healthcare assistance and management dimensions in their professional work practice.

Data was collected in pre-established locations by researchers and participants (most held in their workplace) between February and April 2010, after a pre-test to validate the data collection instrument. Semi-structured interviews were conducted according to the following topics and guiding questions: 1 . Undergraduation preparation for management and practical elements learned in the graduation: How do you consider your preparation for managerial performance was? Correlate your answer to graduation training, continuous education and training service or continuous education; 2. Gaps in management training and suggestions for change: What management training gaps have you noticed in your graduation, now that you are in the field? Make suggestions for changes (content, methodologies, learning opportunities, practice fields).

The interviews were recorded with the permission of the participants, and data collection occurred after study guidance and signing of an authorization consent form for recording. 30-50 minute interviews were held at pre-established locations agreed on by the researcher and participant.

For data analysis, the Collective Subject Discourse technique was used ${ }^{(9)}$. The Collective Subject Discourse technique is a synthesis drawn from pieces of similar meaning speech from different people, then gathered into one speech, which is based on the Social Representation Theory and its sociological assumptions. This qualitative data tabulation and organization technique allows grouping statements without reducing them to quantities, through systematic and standardized procedure ${ }^{(9)}$.

The authors of this technique proposed that it creates methodological figures of speech to make up the Collective Subject Discourse: Key Expressions, Main Ideas and Anchors ${ }^{(9)}$. The technique consists of analyzing the verbal material collected containing raw testimonial research material, then extracting the Main Idea and/or Anchors and their corresponding Key Expressions from each statement; Using Main Ideas/Anchors and Key Expressions, one or more synthetic discourses are composed, representing the Collective Subject Discourse ${ }^{(9)}$.

Key Expressions are excerpts of verbal material that best describes content. Main Ideas are a name or linguistic expression which best describes the specific meaning of the present claims in each of the analyzed speeches and each homogeneous set of Key Expressions, as shortly and as reliably as possible. The Main Idea is the description of the meaning of a statement or set of statements ${ }^{(9)}$. 
Anchoring is a linguistic manifestation that describe ideologies, values and beliefs present in the verbal material of individual responses or responses that have been grouped due to explicit discursive marks in the verbal material of general statements ${ }^{(9)}$. Since such marks were not found in the collected verbal material for this study, Anchoring was not used.

The Collective Subject Discourse consists of a speech synthesis, written in the first person, containing the Key Expressions and the same Main Ideas or Anchors ${ }^{(9)}$. Therefore, the Collective Subject Discourse is a qualitative research technique designed to represent a collective speech, as if it were a single individual.

The ethical aspects contained in the National Health Council Resolution 196/96 (current at the time) relating to research with human beings were respected; data collection was conducted only after Health Sciences Sector, University Federal of Paraná assessment approval. The study was approved by the Committee under the registration number: 795.130.09.

Data collection began after information and clarification about the research was completed and Consent Forms (in two copies) were signed by the research subjects as a way of ensuring confidentiality and anonymity of the information contained in this study. The second copy of the Consent Terms as well as data collected will be kept by the researcher for a period of five years.

\section{Results}

The results showed that most of the graduates completed the course in 2008, although the research population contained graduates from 2007, 2008 and 2009. Of these 22 graduates, 14 (63.6\%) were female and eight $(14,63.6 \%)$ were male. Most of these graduates $(n=20,90 \%)$ were from Foz do Iguaçu/Paraná municipalities, one (5\%) from the neighbouring city Medianeira/Paraná and one (5\%) from Belém/Pará.
With the exception of the student from Para, the interviews were conducted in Foz do Iguaçu in a place chosen by the participant, mostly being their workplace since even the participants who live in neighboring cities work in Foz do Iguaçu. The Pará participant's interview was conducted by Windows Live Messenger.

For speech analysis the methodological figures of speech used were: Key Expression, Main ideas and Speech Synthesis (Collective Subject Discourse), according to the technique's authors' recommendations. The results are presented in the same order of questions that guided the interviews with the first theme centering on the core ideas of undergrad preparation for nursing management and undergrad influence on capacitation. The second issue centers on practical elements learned in graduation, with central themes consisting of the use of management tools in management actions, people management, physical and environmental materials, and management of nursing care. So in the last issue, gaps in management training and suggestions for changes were summarized by the central ideas of lack of practical disciplines and suggestions for change.

The following is the Collective Discourse 1: University offers little preparation because in my internship I just observe and I don't experience nursing attitudes. Moreover, immaturity of the student and short and poor training play an important role. I thought that the administration subject was not important.

The analysis of these speeches shows that the graduates do not feel prepared for managerial work. This is because they address the lack of articulation between theory and practical, curriculum fragmentation, insufficient discipline hours, difficulties related to internship opportunities and practice, in addition to immaturity of students in recognizing the importance of the discipline in the undergraduate curriculum.

For the theme of practical elements learned in their undergraduate studies, we have the following speeches: The Collective Subject Speech 2: I plan projects, care, costs and the evaluation team. Supervise and manage the 
time, mediate conflicts, give leadership without authoritarianism and positioning. Having good interpersonal skills, communication and creativity to make decisions and solve problems.

The collective subject 2 speech showed the nurses' managerial actions which are needed, and the nurse absorbs work that is focused on productivity and management activity focused on institutional needs. Collective Subject Discourse 3: I work in the recruitment and selection of nurses and perform evaluations. I also do permanent and continuing education training when there is any difficulty and training for new employees. I manage staff task scales, I coordinate and supervise the teams, manage renovations and I control equipment, material and bed management.

In the Collective Subject Discourse 3, performance evaluation and how the nurse has to act emerged. It is important to question whether the evaluation model is consistent with routine work or if the subject is implementing a new evaluation model to propose changes. In this speech, staff dimensioning was used in the daily work shift to show conceptual confusion. Materials management is presented in speech as a task held for the institution, that is it happens as the need of the moment. There is medium and long term planning in the speaking of the subject.

Collective Subject Discourse 4: I visit patients, checking the room and if bandages were replaced, I collect test samples, I sort patients, I listen to their complaints, I write in their medical chart and hand it to the doctor. I perform programs well, I do home visits, nursing reports, pending examination and medication. I do the planning of nursing care.

In the collective discourse 4 , the central idea is management of nursing care, shown clearly illustrated as the assistance of environmental management with the assessment actions and control over the care provided by the nursing staff. Still, the focus was identified to organize and select health care information for transfer to the doctor in the hospital.

Theme gaps in management training and suggestions for change in management training emerged as the central idea gap in the practice of the disciplines with the Collective Subject Discourse 5 and suggestions for change in collective subject 6 speech.

Collective Subject Discourse 5: The Administration internship was very weak, they should be carried out in hospital-schools so we could make decision mistakes and learn before entering the market. During the internship we are only observers, practice is not palpable. What was seen in theory does not apply in practice because it lacked a simulation of situations. My internship teacher was not an expert in the area of Administration and she was inexperienced.

It is notable that the Collective discourse 5 reflects a gap in training related to a lack of opportunity to experience management practices in scenarios that allow such learning. Classes can not only have a theoretical approach, but theoretical and practical, and practical activities should be supervised. It suggests the need for practical activities with real simulations, and the need to strengthen partnerships with Supervised Practice Activities in scenarios and strategies of Education Policies.

The Collective discourse 5 showed the need for changes that come from structure. The criticism made in the speech cannot be perceived in the person, the uniqueness, or exclusively focused on the teacher's work, but in particular to the dimension of the course and structural education policies that ensure a stable headcount of qualified teachers in their subjects.

Collective Discourse 6: Committed teachers, a more practical internship and hospital-schools. Practical classes must occur oncomitant with theory; and theoretical subjects should amount to the same or more hours as practical subjects, divided into modules. Administration course content should be embedded in all other subjects. Extracurricular internships and visits to other institutions in order to observe the nursing manager are needed. Simulating situations to experience real problems.

In the Collective Subject Discourse 6, the subjects showed the timeline that breaks the discipline and the distance between the theoretical and practical content. It also highlights the need for interdisciplinarity in progress at the time the graduation puts the importance of working administration of Nursing 
content along with other disciplines. Extracurricular visits, simulations, and following nurses who perform more formal management functions as unit managers or others are suggested strategies.

\section{Discussion}

The collective subject 1 discourse analysis suggests the need for active methodologies in the discipline to facilitate the articulation of theory and practice, as well as curricular adjustment that provides practical hours in appropriate scenarios for the development of managerial skills, seeking support for the construction of attitudes in professional practice.

The management dimension of nursing work comprises operations and complex actions, regardless of the location being in a hospital or primary care ${ }^{(10-11)}$. Facts like this require the nurse to have technical skills in addition to those related to attitude and cognition in order to suit the trends of current management models $^{(11)}$.

Nevertheless, the issue of student motivation for Administration courses in Nursing is apparent. It is inferred that the environment did not motivate the student, and the low set of administrative content hours is not enough to involve them in the discipline. Curriculum fragmentation was evident with few consolidation practice opportunities in scenarios that impede arousing interest in students who do not see the application of the content in practice.

Therefore, it is considered that the teaching-learning process is synchronous and the role of the student is extremely important. The need for their cooperation and commitment with regard to the management disciplines applied to Nursing, created with teaching opportunities in order to learn more dynamically and interactively ${ }^{(10)}$.

A study of the formation of knowledge, skills and managerial attitudes showed that it is difficult to develop the attitudinal field in professional nursing practice. Thus, the authors consider the need to provide training, teaching and learning situations in order to develop knowledge on which to base the approach to be exercised in the workplace ${ }^{(12)}$.

To this end, it is necessary that the teaching-learning in these disciplines must occur through methodology and planning in line of theory and practice with real work situations, thus allowing for knowledge interpreted according to the context ${ }^{(11)}$.

In the collective subject 2 speech, the issues of human relationships and communication are toward conflict management and for taking immediate decision. Clearly, in this speech perception difficulties of management actions permeate the practice. For nurses to become leaders and a better managers, they need to understand the concept of leadership and how to develop the skills to do $\mathrm{so}^{(13)}$.

A response to the Collective Subject Discourse 3 would be the performance evaluation of competencies; to evaluate the preparation of the nursing team to enter the institutional context, to train professionals to be aware of their abilities and attitudes that correspond to the organization's expectations.

The management dimension of nursing work when understood as a structured social practice has an important role in the construction of a health care form focused on the need for health ${ }^{(7)}$.

In the Collective Subject Discourse 4, the knowledge that is used by graduates provoked reflection on the political dimension of the management process for the instrumentation and driving of a critical-reflexive action against real work situations.

It is noticed that speech, as found in the study, still dominates the discourse of nurses and their behavioral practice clarifies the dichotomy between care and administration, as if they were antagonistic and synchronic dimensions. More evident is the conceptual confusion between them, about the actions of nursing care management in ignorance of the process of caring work that are direct care and administrating as indirect care such as in practicing the management of nursing care ${ }^{(14)}$.

Analysis of the results of this research puts the landscape of nursing education in the twenty-first 
century into reflection. For this, it warrants analyzing the context the influence of globalization on health systems impacts contemporary models of health education, and identifies a number of challenges for this century ${ }^{(15)}$.

Findings from the speech of collective subject 5 indicates that the researched institution has a reduced number of teachers (especially in nursing administration disciplines), who are working with a number of part-time teachers with more than one work relationship, decreasing the possibility of dedication to the area of knowledge and discipline to make reference to the service, but it is important positioning in the institutional partnership of education/service.

The Unioeste Nursing Course of Foz do Iguaçu was established in 2003 and operates full time, with annual availability of 40 spots. The minimum time for completion is 4.5 years and the maximum 8 years. The total course workload is 4929 hours, and of these 267 hours are academic enrichment activities. It offers Bachelor's and Teaching Degrees. Authorized by the Federal Decree N. 3.637/78 of 09/20/2004, and recognized by Decree N. 5.398, of 09/14/2009; with Curriculum Structure approved by Resolution N. 264/2004-CEPE(16).

The curriculum sets disciplines considered basic and those relating to the degree in the first period. Disciplines related to the professional performance of the nurse as well as supervised training of both modalities are set in the last period. The supervised Bachelor training is set in the last periods of the course, while the Degree is set in the 3rd and 4th periods ${ }^{(17)}$.

For the difficulties presented by the graduates and their suggestions in the collective subject 6 speech, it seems necessary to establish a partnership between the university and practice settings, for education and extension projects. The partnership helps the professional to understand the learning needs of the student and to share in teaching situations of daily work that are learning opportunities for them.
Regarding the fragmentation of education, differences and similarities, it is important that the teacher helps in the academic training to be performed in any space. The technical visits are strategies for the student to experience other fields of activity without compromising the continuity of care actions provided for greater permanence in the institution because fragmentation can weaken partnerships with learning fields.

The nursing teachers need participation in the training of the student as when the students initially graduate from nursing, they are inexperienced with the training process but they are gradually transformed to become a professional, equipped with theoretical knowledge and technical skills ${ }^{(18)}$.

It's important to note that the managerial dimension of the nurses' working process as well as being crafted in undergraduate program needs to be supplemented with continuing education practices in health services ${ }^{(19)}$.

\section{Conclusion}

The managerial actions of nurses in their daily practice are directed to making and using the principles of scientific administration, which emphasize technical competence in the delivery of customer service. The work is still focused on productivity, and the managerial activity is focused on institutional needs.

This study brings a contribution to evaluation of management in nursing education from the graduates' own perspective; from those that have experienced the theme in their professional practice. The discourses explain that the dichotomy between assistance and management is present in managerial performance idealized by nurses which impedes their integration in care practice. As a result, the professional disregards the managerial dimension of their work, as they relate to management of formal responsibilities.

The information captured in the Collective Subject Discourse converged to enter the scenarios of 
management actions carried out by graduate nurses, along with their difficulties, expectations and frustrations.

The challenge for the changes and transformations in management education of nurses as focused on in this study also refers to the need of teachers to transform their operations. We must overcome resistance to change, invest in their teaching practice with training to improve the teaching-learning process, and reduce the separation between theory and practice. This issue does not end with this study given that this dealt with a specific scenario of formal training, so future research on managerial training of nurses and their preparation for the world of work is necessary.

\section{Acknowledgements}

To Paraná Araucaria Foundation, Brazil, for financial support of this research, process $\mathrm{n}^{\circ} 16.262$.

\section{Collaborations}

Almeida ML contributed to the project design, data collection analysis and interpretation of data. Peres AM, Bernardino E and Santos MF contributed to project design, analysis and interpretation of data, and critical review of the relevant intellectual content.

\section{References}

1. Paim JS. A Constituição Cidadã e os 25 anos do Sistema Único de Saúde (SUS). Cad Saúde Pública. 2013; 29(10):1927-53.

2. Ministério da Educação (BR). Resolução CNE/ CES n. 3, de 7 novembro de 2001. Institui as diretrizes curriculares nacionais do curso de graduação em Enfermagem. Brasília: Ministério da Educação; 2001.

3. Felli VEA, Peduzzi M, Kurcgant P, Ciampone MHT. Trabalho gerencial dos enfermeiros. PROENF Gestão. 2011; 1(1):11-39.
4. Lima JR, Felli VEA, Cabral IE, Vale EG. Programa de Atualização em Enfermagem. PROENF Gestão. 2011; 1(1):9.

5. Conselho Federal de Enfermagem. Lei no7. 498, de 25/07/1986: Dispõe sobre a regulamentação do exercício profissional da Enfermagem. Rio de Janeiro: COFEN; 1986.

6. Erdmann AL, Santos JLG. Gestão em enfermagem e cultura da excelência no processo de cuidar. PROENF Gestão. 2012; 2(2):111-39.

7. Felli VEA, Peduzzi M. O trabalho gerencial em Enfermagem. In: Kurcgant $P$, coordenador. Gerenciamento em Enfermagem. 2 ${ }^{\underline{a}}$ ed. Rio de Janeiro: Guanabara Koogan; 2010. p. 1-13.

8. Minayo MCS. O desafio do conhecimento. 12 ed. São Paulo: Hucitec; 2010

9. Lefevrè F, Lefevrè AMC. Pesquisa de Representação Social. Um enfoque qualiquantitativo. A metodologia do Discurso do Sujeito Coletivo. Brasília: Liberlivro; 2010.

10. Llapa-Rodríguez EO, Carvalho TS, Gois CFL, Guimarães AMDN. Vivências dos estudantes de pré-grau com as matérias de administração de enfermagem. Invest Educ Enferm. 2012; 30(1):8794.

11. Baldissera VDA, Góes HLF. O Método Altadir de Planificação Popular como instrumento de ensino da gerência em enfermagem. Invest Educ Enferm. 2012; 30(2):252-9.

12. Almeida ML, Peres AM. Conhecimentos, habilidades e atitudes sobre a gestão dos formados de enfermagem de uma universidade pública brasileira. Invest Educ Enferm. 2012; 30(1):6676.

13. Marquis BL, Huston C. Administração e liderança em Enfermagem: teoria e prática. 6 ${ }^{\underline{a}}$ ed. Porto Alegre: Artes Médicas; 2010.

14. Christovam BP, Porto IS, Oliveira DC. Nursing care management in hospital settings: the building of a construct. Rev Esc Enferm USP. 2012; 46(3):73441.

15. Vega YV. La administración que se enseña en el pregrado de enfermería. Av Enferm. 2012; 30(1):95-106. 
16. Universidade Estadual do Oeste do Paraná. Sobre o Curso de enfermagem [Internet]. [citado 2014 jun 15]. Disponível: http://www.UNIOESTE.br/ campi/foz/

17. Universidade Estadual do Oeste do Paraná. PróReitoria de Graduação. Projeto Político Pedagógico do Curso de Enfermagem da UNIOESTE, Campus Foz Do Iguaçu; Paraná: UEOP; 2004.
18. Maithe CL, Joanir PP. Satisfação e frustração no desempenho do trabalho docente em enfermagem. Rev Min Enferm. 2012; 16(1):48-55.

19. Senna MH, Drago LC, Kirchner AR, Santos JLG, Erdmann AL, Andrade SR. Meanings of care managementbuilt throughout nurses' professional education. Rev Rene. 2014; 15(2):196-205. 